University of Chicago Law School

Chicago Unbound

Public Law and Legal Theory Working Papers

Working Papers

2017

\title{
Can It Happen Here?: Donald Trump and the Paradox of Populist Government
}

Eric A. Posner

Follow this and additional works at: https://chicagounbound.uchicago.edu/public_law_and_legal_theory

Part of the Law Commons

Chicago Unbound includes both works in progress and final versions of articles. Please be aware that a more recent version of this article may be available on Chicago Unbound, SSRN or elsewhere.

\section{Recommended Citation}

Eric Posner, "Can It Happen Here?: Donald Trump and the Paradox of Populist Government," University of Chicago Public Law \& Legal Theory Paper Series, No. 605 (2017).

This Working Paper is brought to you for free and open access by the Working Papers at Chicago Unbound. It has been accepted for inclusion in Public Law and Legal Theory Working Papers by an authorized administrator of Chicago Unbound. For more information, please contact unbound@law.uchicago.edu. 


\section{CHICAGO}

PUblic LAW AND LegAL TheORY WORKING PAPER NO. 605

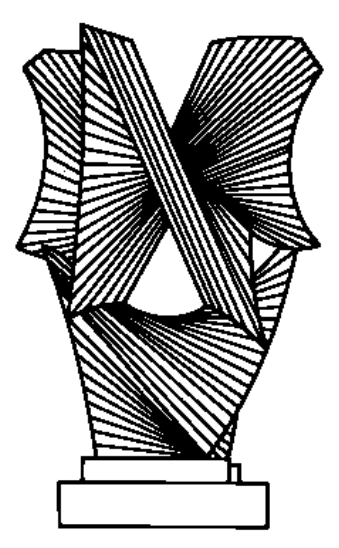

CAN IT HAPPEN HERE?: DONALD TRUMP AND THE PARADOX OF POPULIST GOVERNMENT

Eric A. Posner

THE LAW SCHOOL

THE UNIVERSITY OF CHICAGO

January 2017 


\title{
Can It Happen Here?: Donald Trump and the Paradox of Populist Government
}

\author{
Eric A. Posner ${ }^{1}$
}

January 3, 2017

\begin{abstract}
Donald Trump campaigned as a populist but how can a populist who blames the "establishment” for the country's failures, rule, when the government bureaucracy is itself a creature of the establishment? The answer that appears to be emerging is a "personalist" style of leadership that may be popular in the short term but is unlikely to achieve any of Trump's goals. If Trump wants to be effective, he will need to adopt a bureaucratic style of governance that will, however, require him to rely on the elites he has disparaged, disappointing his followers, converting him into a conventional president, and very likely ruling out the type of authoritarian regime that Trump's critics fear.
\end{abstract}

Donald Trump's election to the presidency has sparked a crisis in political thinking in the United States. Many of Trump's methods, promises, and ideas violate constitutional understandings shared by liberal and conservative intellectuals, as well as by establishment politicians, journalists, and civic leaders. His victory raises questions about formerly taken for granted political and constitutional norms. How Trump will govern is a mystery that will unveil itself slowly. He may find that unorthodox measures do not work, in which case he may be rendered ineffective or forced to act like his predecessors. But if those measures succeed, Trump's presidency may set the stage for a new type of presidency in the future.

Whatever happens, we need to understand the constitutional ideas that Trump embodies - if only to understand the political context in which those ideas flourish and may repeat themselves. I will refer to those ideas under the rubric of Trumpism. This chapter is an exploration of what Trumpism means. I argue that Trumpism is a style of presidential administration that hovers uneasily between two approaches to political authority in a presidential system: bureaucratic

\footnotetext{
${ }^{1}$ Kirkland \& Ellis Distinguished Service Professor, University of Chicago Law School. Written for "Can It Happen Here?” (Cass R. Sunstein, ed., forthcoming). Many thanks to Curt Bradley, Will Howell, and Daryl Levinson for very helpful comments, and to the Russell Baker Scholars Fund for financial support.
} 
authority and personalist authority. ${ }^{2}$ The answer to the question whether or not "it can happen here" ${ }^{3}$ depends on whether Trump will embrace personalist authorityas opposed to adopting the bureaucratic methods of his predecessors. If he takes the route of bureaucratic authority, he will likely govern pluralistically and within the American constitutional tradition (whether he governs well or badly is another question), but will disappoint his followers, who expect personalist rule. If he takes the personalist approach, he will very likely turn out to be an ineffective president, though he may do damage to the country and to constitutional norms, paving the way to a more authoritarian system or provoking a democratic reaction.

Trump, the billionaire, ran for office as a classic populist. He hit all the populist themes: the domination of the elites; the failure of technocracy; the corruption of the political class; and their neglect of the people. But he is the first populist to win the office of the president, where he will face the question how to govern in a way that is true to the populism. The paradox of populist government is that a candidate who runs against the establishment cannot govern without the establishment. To be sure, many presidents—including Barack Obama — ran as outsiders, who, as outsiders, could claim to be uniquely capable of overcoming partisan differences, breaking through barriers to reform embedded in the Washington political culture, and steamrolling entrenched interests. But this was always more a matter of political rhetoric than actual intent, and all of them made their peace with the establishment once in office, where they took a bureaucratic rather than personalist approach to governance. What is unique about Trump is that his populist rhetoric was significantly more intense and, in light of lack of political experience, more credible. The logic of his position, and the way he conducted his campaign and transition, suggest that he is attracted to personalism as an alternative form of governance. How that would work in our constitutional system is the question examined in this chapter.

\section{Bureaucratic Authority Versus Personalist Authority}

By bureaucratic authority or leadership, I mean to refer to the system of presidential primacy that has existed in this country at least since the New Deal, and arguably since Woodrow Wilson or even Theodore Roosevelt. This type of presidential leadership emerged as the decentralized Madisonian system of separation of powers and federalism established in the founding document gave

\footnotetext{
${ }^{2}$ On personalist styles of leadership, see, e.g., Barbara Junisbai, Improbable but Potentially Pivotal Oppositions: Privatization, Capitalists, and Political Contestation in the Post-Soviet Autocracies, 10 Perspectives on Pol. 891 (2012).

3 Sinclair Lewis, It Can’t Happen Here (1935).
} 
way in the twentieth century in the face of demands for a more centralized and hierarchical national government. Congress vested immense powers in the presidency and acquiesced as successive presidents relied on aggressive interpretations of their constitutional powers in order to justify economic regulation at home and control over foreign policy. Courts gave their stamp of approval. The two branches can slow down and occasionally block presidential initiatives but they rarely originate policy or stand in the way during crises and other moments of great political importance. ${ }^{4}$

Yet the president remains bound by a range of political and practical constraints. He operates through his appointees, who bring to the job their own preferences and agendas, and those appointees in turn must operate through a vast bureaucracy, whose path is mainly determined by inertia. He is sensitive to public opinion because of worries that he or his party could lose the next election, and that a hostile successor could reverse his accomplishments. As a result, he must also labor to appease the press, and this means being relatively open about internal deliberations, disclosing information otherwise hidden in the executive branch, avoiding scandals, and making decisions that benefit the country or at least please - or do not excessively displease - the leaders of the press, industry, religion, labor, and other groups, and watchdogs of various sorts.

The president-as-bureaucratic-leader is like the CEO of a large corporation. Although he possesses immense prestige and formal power, he must usually defer to the judgments of lower-level officials while constantly mollifying his fairweather supporters. He relies on a colossal, powerful, and sluggish bureaucracy because only such an institution can manage the complexity of the environment. A successful president, like a successful CEO, relies more on his powers to obtain advice, resolve disputes among subordinates, and flatter and cajole, than on his formal authority to command, which can (in principle) be eroded or taken away at a moment's notice. When he evaluates information, he takes advice from all affected groups; when he makes a decision, it is usually to confirm a consensus among subordinates and otherwise to resolve disputes between competing groups of subordinates; when he communicates to the public, he uses a carefully vetted script.

CEOs of large corporations rarely operate in a personalist way. The alternative model - the personalist approach—is characteristic of entrepreneurs who launch start-ups or lead small businesses in volatile industries. Personalist

\footnotetext{
${ }^{4}$ Eric A. Posner \& Adrian Vermeule, The Executive Unbound (2010).
} 
presidents, as I understand them, attempt to evade bureaucratic and other institutional constraints by disregarding bureaucratic advice, working outside the party system, and appealing directly to the people.

The United States has never been led by a personalist president. Figures who might come to mind-Andrew Jackson, Franklin Delano Roosevelt, or Ronald Reagan-were popular and charismatic, but mostly operated through the bureaucracy and relied heavily on their subordinates. Jackson is the closest precedent. He was an outsider by the standards of the time and a charismatic figure, and he drew support from the masses, who had been disregarded by political elites. But he was also an experienced politician and government official before he became president. Roosevelt was the only peacetime president who enjoyed arguably temporary quasi-dictatorial powers but he worked through the party system, enjoyed significant support in Congress and in the public, and could hardly have been more closely identified with the establishment. Reagan clashed with the bureaucracy but with very modest success; his greatest accomplishments involved congressional support except in the area of foreign policy, the traditional prerogative of the president. Reagan, too, was an establishment figure with significant government experience prior to his election to the presidency.

But this history illustrates an important theme of the American presidency: personalism emerges from efforts by presidents to overcome institutional checks, including Congress, the bureaucracy, and the press. ${ }^{5}$ Theodore Roosevelt originated the idea that the president should appeal to the people over the head of Congress, but he could appeal to the people directly only by making speeches, which could be heard by a limited audience. Otherwise, he communicated through the press, which served its own checking function by editing, commenting on, or ignoring his arguments. Franklin Roosevelt partially circumvented the press by broadcasting speeches over the radio, a practice revived by Reagan. But by Reagan's time, radio had lost its dominance as a medium of communication, and his message was diluted by Democratic responses broadcast immediately after Reagan's speeches. Trump has discovered that he can communicate effectively through Twitter. He uses humor, insults, and pithy statements to convey his views and denigrate his opponents, while linking to websites that (in return for valuable hits) supply stories - true or false - that support his views. Technology in politics as in other areas has eliminated intermediaries, providing an advantage to populists who seek to make direct connections with the people. But it does not necessarily make governing any easier, a point to which I will return.

\footnotetext{
${ }^{5}$ Cf. Richard Neustadt, Presidential Power and the Modern Presidents: The Politics of Leadership (1960).
} 
Personalism Versus Populism

Personalism is different from populism, but the two phenomena are linked. Populism is characterized by an anti-establishment (anti-elite) stance, and is typically anti-pluralist as well. ${ }^{6}$ Populism is a reaction to the perceived failure of elites to govern in the interest of the public. The left-right divide shifts on its axis as the public (or a large portion of it) unites and turns against the establishment, hoping to punish it for its failures and to replace it with a "man of the people." In the United States, the Iraq War, the financial crisis, and a long period of economic stagnation tainted both party establishments—which were jointly responsible for these failures - and refuted the claims of technocracy. Sanders and Trump emerged as flag bearers for populist movements. And while the populists divided into left and right—with the left ultimately supporting Clinton and the right supporting Trump-Trump benefited from the lack of enthusiasm of the populist left for Clinton, an establishment candidate, and from the enthusiasm of a core group of populists who were either Republicans or politically alienated.

The great vulnerability of populism is that the "people" cannot govern directly; it must govern through agents, and if agents are competent and experienced, then they must come from the elite. Sanders was, of course, a senator. As is typical of populist politicians, he came from the establishment while presenting himself as anti-establishment, helped in this case by his youthful dalliance with socialism. Trump may have appealed to people because he was not a politician, but he was hardly an anti-establishment figure. He was (and is) a billionaire who has hobnobbed with politicians for decades. Trump overcame this obstacle through tactical behavior on the campaign trail—above all, by not acting like a member of the establishment. He insulted his political opponents and threatened Hillary Clinton with jail. He disparaged women, Hispanics, disabled people, and African-Americans. He publicly used obscenities. ${ }^{7}$ While all politicians lie and make promises they cannot keep, Trump went farther, lying in ways that were easily detected, generating outrage among establishment figures that further distanced Trump from them. He subtly encouraged violence. All of

\footnotetext{
${ }^{6}$ See Jan-Wenner Müller, What Is Populism? (2016). Müller argues that populism is inherently anti-pluralist. I do not think this is an accurate description in either its historical or modern form, but there is often an anti-pluralist tendency in populist movements. See also John B. Judis, The Populist Explosion (2016), who (correctly, in my view) puts less emphasis on anti-pluralism.

${ }^{7}$ Interestingly, vulgar talk is characteristic of populist politicians, who in this way distinguish themselves from the elites simply by choice of words. See Judis, on Stammtisch.
} 
these actions, by distinguishing Trump from establishment figures, helped establish his populist bona fides.

The paradox of populism is that it comes to power on a wave of anti-elite, anti-establishment, anti-technocracy anger, but then it must govern, and how can the "people" or their leader govern without relying on the establishment? The government exerts its power through a bureaucracy. The bureaucracy is a typical establishment institution — on par with the courts, the universities, and big business. Bureaucracies are staffed by university-trained technocrats who have a large stake in the status quo. ${ }^{8}$ They are constrained by rules and governed by law. They move slowly, and so are, with minor exceptions, wholly unable to respond to popular sentiment when it changes rapidly. Their watchwords are impartiality and caution. Because bureaucracies are staffed by people from the different parties and with different political views, and take their marching orders from statutes that reflect compromises between different interest groups, bureaucracies are pluralistic. If the populist president relies on the bureaucracies as normal presidents do, he can accomplish things, but not the sorts of things that his supporters demand from him, and not in the way they demand them. He abandons populism for technocracy and pluralism.

The more natural approach for the populist is personalism. He takes charge and calls the shots, channeling the Will of the People. Hugo Chavez took calls from the public during his weekly TV show and while still on air ordered government officials to address complaints. ${ }^{9}$ Trump has already shown a propensity in this direction. Even before taking office, he threatened and cajoled Carrier Corporation into keeping jobs in Indiana where the normal approach to fighting unemployment would be to support legislation or new regulations. He has also picked fights with Boeing and Lockheed. But threatening individual companies and conducting one-on-one negotiations with them is political theater. It is not an effective way to reduce unemployment or manage the economy. That is what bureaucracies are for. If a populist president is committed to personalism over bureaucratic leadership, how is he to get anything done?

Another way, of course, is for the populist leader to replace the bureaucracy with his own people. But there are two problems with this approach. First, it takes a long time. The populist must either wait for civil servants to retire or obtain legislation that allows him to replace them, and, in the case of any large

\footnotetext{
${ }^{8}$ With the important exception of the military, which raises interesting questions (many populist regimes are established by military leaders) but not of relevance (so far) to the American case.

${ }^{9}$ Müller, supra.
} 
bureaucracy, the process of replacement is logistically complex. Chavez, for example, spent many years remolding Venezuela's political institutions in order to enhance his power and undermine the opposition. Second, while in the long term, the populist leader may be able to remold the bureaucracy in his own image as loyalists self-select into civil service positions or the president persuades a compliant legislature to erode civil service protections, the dilemma never goes away. Either the president hires competent, university-trained, establishment technocrats who act in the normal bureaucratic way, or he blows up the systemwhich hurts the country in the long run and his own political standing, as illustrated by the long history of failed populist despots from Hitler to Chavez.

A final approach, and the one with the most impressive pedigree among history's dictators, is to create a paramilitary — a private army that is more or less disciplined and controllable, something more than a mob. ${ }^{10}$ Brown shirts can be used directly to operate the instruments of state, but more commonly they are used at the initial stages of power consolidation to intimidate political opponentsincluding journalists, activists, opposition leaders, and recalcitrant bureaucrats. But while during the campaign Trump would whip up his audiences into a frenzy from time to time, and briefly encouraged mob violence, he has not tried to create a paramilitary or showed any inclination to use bribery and corruption at the level that would be necessary to attract people from the police or armed forces. Nor does it seem feasible for him to do such a thing-we are not living in the 1930s, when there were millions of desperate, unemployed young men who could have formed his cadres.

Trumpism

Trump's approach to this dilemma is as yet unknown, but some evidence suggests that he will weave back and forth between bureaucratic and personalist leadership. Consider, for example, his threat while on the campaign trail to prosecute Hillary Clinton once he reached office. Prosecution of political opponents is a classic tactic of populist leaders; it is an expression of the antipluralism of populism. Yet once he won the election, Trump backed off from this threat, signaling that-in this respect—he will play by the rules of the constitutional system.

\footnotetext{
${ }^{10}$ Emphasized in the two most famous novels that dramatized the rise of a populist authoritarian, Sinclair's It Can't Happen Here (1935), and Robert Penn Warren’s All the King's Men (1946).
} 
What exactly would have been wrong with prosecuting Hillary Clinton, who likely violated the law against mishandling classified information? Democracy is distinguished by its commitment to the principle that a loyal opposition can exista principle rejected by authoritarian states. Thus, when important leaders of the opposition break the law, democratic governments tend to avoid prosecuting, as illustrated by President Obama's refusal to prosecute Bush administration officials who authorized torture. Populists' anti-establishment stance leads them to reject this principle - and this is one of the reasons that populism is often identified with latent or actual authoritarianism. By refusing to prosecute Clinton, Trump threw his lot with pluralism.

Trump's involvement with Carrier was personalist, but it does not seem that he can replicate this approach on a wide scale, while he seems likely to use the ample regulatory and legal tools at his disposal to implement his trade policies. If he does so, he will need to work through the trade bureaucracy and Congress; authorize investigations; make findings; defend against judicial challenges; and do all the other things that are required for bureaucratic leadership. All these processes create opportunities for delay and reversal, and offer Trump's opponents avenues for participating in policy making. Trade policy, to be effective, must be bureaucratic and hence pluralistic, rather than personalist and populist.

Much has been made of Trump's demonization of illegal immigrants, and his disparaging comments about Hispanics and African-Americans. This approach follows the populist playbook, in which an in-group of common people who compose a numerical majority of the country are defined through the exclusion of a shadowy enemy of foreigners and minorities who are in cahoots with financiers and other elites. Yet Trump's populism is muted by historical standards. Significantly, he focused his hostility on illegal immigrants rather than immigrants generally, in this way uniting his populist appeals to a legalist sensibility that is common in the United States but wholly foreign to populism. His racism and misogyny were advanced in winks, insults, and scattered comments; they were not central to his message, except to the extent that anti-Hispanic sentiment fueled the enthusiasm for his anti-immigrant stance. Unlike most populists, he did not appeal to orthodox morality or religious sensibilities-perhaps because his own character disqualified him — and instead obtained evangelical support by offering opposition to abortion rights as a pragmatic quid-pro-quo, in the spirit of pluralism rather than populism. The major policy implication was, of all things, enforcement of existing immigration laws, on which he can rely on an eager bureaucracy if he can obtain sufficient funds from Congress. Whether this will be sufficient to satisfy his supporters remains to be seen. 
One of the few reliable sources of information about Trump's methods and motives at this early stage comes from his cabinet nominations. A populist might be expected to nominate fellow travelers-outsiders and commoners, or at least people who have made a career of representing ordinary people. Yet Trump has filled his cabinet with plutocrats and military men. Here, it seems that Trump's establishment instincts supersede populist politics. Trump feels comfortable among business people rather than farmers and factory workers. Most of his appointees are not populists; they are establishment business figures and (military) bureaucrats of the sort who would have fit the priorities of a George or Jeb Bush. Moreover, his short list for the Supreme Court consists of establishment conservativesmostly sitting judges — rather than political operatives or populist ideologues.

Indeed, it is far from clear where Trump would find the sorts of people who would support a populist program. Unlike other successful populist leaders, Trump has not tried to create his own party or take over an existing party. He cannot draw on a pool of loyal, experienced supporters to fill positions. Trump will be forced to rely on the Republican party to help staff the government, and those people will be establishment elites rather than bomb-throwing populists.

A final distinctive element of Trump's presidency is business entanglement. Commentators have noted that populist leaders are often corrupt and their corruption does not bother their supporters, possibly because populists tend not to be legalistic and may support the populist leader in the first place because of his contempt for legal norms. (Outside the United States, many populists establish their populist credentials by violating the law, like Chavez or Duterte.) It remains to be seen whether these legal complications will help rather than hurt Trump. As long as the judiciary remains independent, lawsuits will provide a never-ending source of damaging information for Trump's political opponents to exploit. No American president has ever benefited from being embroiled in scandals. A populist who rides to victory on the strength of his anti-establishment credentials when those credentials involve law-breaking will find it difficult to govern unless he can distance himself from his misdeeds.

\section{Can It Happen Here?}

Trumpism is not fascism. Trump's rise to power reflect two strong themes in American history. The first is political and economic nationalism. Americans have always put America first, and demanded that their leaders pursue policies that benefit Americans even at the expense of other countries. Anti-trade sentiment was 
broad and deep during the Great Depression, of course, but the U.S. was inwardly directed through the nineteenth century as well. Favored with an enormous internal market, the United States always had less to gain from international trade than smaller countries did. It promoted global trade liberalization after World War II in order to consolidate western opposition to the Soviet Union. This Cold War imperative ended almost 30 years ago.

Similarly, anti-immigration sentiment reaches back to the Chinese Exclusion Act of 1882 and hardened in the first decades of the twentieth century. Illegal immigration from Mexico in the late twentieth century was supported by business and some advocacy groups but did not enjoy support among the American public generally. Trump realized that public opposition to uncontrolled borders was deep rather than superficial, and rooted in emotionally plangent considerations of national identity as well as perceived economic interest. While Trump's economic nationalism is objectionable to many people, and sometimes verges on racism, it is hardly unprecedented and in the end merely a policy choice, whether good or bad, and not a challenge to constitutional norms.

A major feature of populism is the claim that the leader speaks for all the people and political opposition is illegitimate, even illegal. Chavez, Erdogan, Putin, and Orban all follow this pattern, which is utterly in contradiction with American constitutional traditions. But does Trump? While Trump has toyed with this idea by threatening to prosecute Hillary Clinton, expressing a desire to strengthen libel laws, and jeering at the press and working around it by using Twitter and supporting alternative websites, he does not seem to be seriously pursuing this approach at the time of this writing. He has tried to reconcile with political opponents in the Republican party and avoided (so far) demonizing Democrats since he won the election. Unlike most modern-day populists, Trump is (so far) deeply unpopular among the public, and seems to realize that he needs the support of people who disagree with him.

Trump's inclinations toward personalist forms of governance are of greater concern. He has shown considerable imagination by exploiting advances in technology to communicate to the public unmediated by establishment institutions like the press. His complaints and interventions are in tension with bureaucratic regularity and rule-of-law values. Yet while these practices are unprecedented and reason for concern, it remains unclear how they will enable him to circumvent the establishment, pluralistic, legal institutions that he ran against. He needs an instrument to turn his statements into action. Thankfully Trump does not have a 
group of brown shirts or a third party at his disposal, and none appears on the horizon.

\section{Constitutional Implications}

Does Trumpism mean anything for the U.S. Constitution? Many people are unhappy that Trump has come to power with a minority of the popular vote. It is an irony, to say the least, that the electoral college - an institution designed to limit the political influence of ordinary people-has handed the laurel wreath to a populist candidate who won less than a majority of the population. But the irony is easy to understand: nowadays, the electoral college system gives an edge to populism by overweighting rural areas in which populism flourishes. If Trumpism fails badly, badly enough to persuade even its supporters that they voted wrongly, then perhaps political support for electoral college reform will materialize. Dizzyingly, there would need to be an anti-populist movement to increase the influence of the popular vote.

A failure of Trumpism could also spur constitutional reform directed at limiting the power of the president, strengthening Congress and the courts, or enhancing individual rights. But such talk is premature. Our system of presidential primacy is the product of a century of constitutional innovation in response to political, technological, and demographic changes that have not gone away. We will need to understand the nature of the Trumpian pathologies - if there are anybefore we can evaluate constitutional reform. 